\title{
Gambaran pemberian terapi pada pasien stroke dengan hemiparesis dekstra atau sinistra di Instalasi Rehabilitasi Medik RSUP Prof. Dr. R. D. Kandou Manado periode Januari-Maret tahun 2016
}

\author{
${ }^{1}$ Rusdyanto Halim \\ ${ }^{2}$ Joudy Gessal \\ ${ }^{2}$ Lidwina S. Sengkey \\ ${ }^{1}$ Kandidat Skripsi Fakultas Kedokteran Universitas Sam Ratulangi Manado \\ ${ }^{2}$ Program Studi Ilmu Kedokteran Fisik dan Rehabilitasi \\ Universitas Sam Ratulangi Manado \\ Email: rusdyanto.halim@gmail.com
}

\begin{abstract}
Stroke is one of the important problems in public health due to its morbidity, mortality, and high cost. In many countries in the world, stroke is the third leading cause of death after coronary heart disease and cancer. This study aimed to obtain the profile of medical rehabilitation treatment for stroke patients with hemipharesis. This was a retrospective descriptive study. Subjects were medical records of stroke patients with hemiparesis at Installation of Medical Rehabilitation at Prof. Dr. R. D. Kandou Hosipital Manado. The results showed that the medical rehabilitation treatment for stroke patients with hemiparesis in the period January-March 2016 in the Installation of Medical Rehabilitation at RSUP Prof. Dr. R. D. Kandou Manado was as follows: physiotherapy with infrared $(31.402 \%)$, classis physical exercise $(27.744 \%)$, active creative exercise $(18.293 \%)$, daily activity adaptation (13.415\%), therapeutic USD (2.449\%), breathing exercise (2.134\%), language exercise $0.610 \%$ ), psychology rehabilitation $(1.829 \%$ ), proper body mechanisms $(1.829 \%)$, and therapeutic medical social $(0.305 \%)$.
\end{abstract}

Keywords: stroke, hemiparesis, therapy

\begin{abstract}
Abstrak: Stroke adalah salah satu masalah penting bagi kesehatan masyarakat karena memiliki angka kesakitan, angka kematian, dan biaya yang tinggi. Di banyak negara di dunia, stroke menduduki peringkat ketiga penyebab kematian sesudah penyakit jantung koroner dan kanker. Penelitian ini bertujuan untuk mendapatkan jenis-jenis penanganan rehabilitasi medik pada pasien stroke dengan hemiparesis. Jenis penelitian ini ialah deskriptif retrospektif. Subjek penelitian ialah data rekam medik pasien stroke dengan hemiparesis di Instalasi Rehabilitasi Medik RSUP. Prof. Dr. R. D. Kandou Manado. Hasail penelitian memperlihatkan pemberian terapi yang paling sering diberikan kepada pasien stroke dengan hemiparesis pada periode Januari-Maret 2016 di Instalasi Rehabilitasi Medik RSUP Prof. Dr. R. D. Kandou Manado ialah fisioterapi dengan pemberian infra merah $(31,402 \%)$, latihan fisik klasik $(27,744 \%)$, latihan aktif kreatif $(18,293 \%)$, adaptasi AKS $(13,415 \%)$, terapi USD $(2,449 \%)$, latihan pernapasan $(2,134 \%)$, latihan berbahasa $(0,610 \%)$, rehabilitasi psikologi $(1,829 \%)$, proper body mechanism $(1,829 \%)$, dan terapi sosial medik $(0,305 \%)$.

Kata kunci: stroke, hemiparesis, terapi
\end{abstract}

Stroke merupakan penyebab kematian kedua terbanyak di negara maju dan ketiga terbanyak di negara berkembang. Baik di negara maju maupun berkembang, beban 
yang ditimbulkan stroke sangat besar. Berdasarkan data WHO tahun 2002, lebih dari 5,47 juta orang meninggal karena stroke di dunia. Dari data yang dikumpulkan oleh American Heart Association tahun 2004 setiap 3 menit satu orang meninggal akibat stroke. ${ }^{1}$

Stroke adalah salah satu masalah penting bagi kesehatan masyarakat karena memiliki angka kesakitan, angka kematian dan biaya yang tinggi. Pada banyak negara di dunia, stroke menduduki peringkat ketiga penyebab kematian sesudah penyakit jantung koroner dan kanker. ${ }^{2}$ Dengan kemajuan teknologi, stroke lebih sering meninggalkan kecacatan dibandingkan kematian. Stroke merupakan penyebab kecacatan kedua terbanyak di seluruh dunia pada individual di atas 60 tahun. ${ }^{3}$

Masalah stroke saat ini ialah penyebab kematian urutan ketiga setelah penyakit jantung koroner dan kanker dan merupakan penyebab utama kecacatan kronik terutama pada orang dewasa. Diantara kecacatan tersebut yang paling sering ditemui ialah hemiparesis, afasia, diasrtria, ataksia, disfagia, inkontinensia urin, dan demensia. ${ }^{4}$

Penelitian di negara-negara ASEAN melaporkan bahwa pasien yang dapat hidup pasca stroke mengalami perbaikan klinis pasca rawat sebesar 57\%, keadaan klinis menetap sebesar $10 \%$, dan memburuk sebesar $3 \%{ }^{5}$

Hasil Riskesdas tahun 2013 menunjukkan prevalensi penyakit stroke di Indonesia meningkat seiring bertambahnya usia. Kasus stroke tertinggi yang terdiagnosis tenaga kesehatan ialah pada kelompok usia 75 tahun keatas $(43,1 \%)$ dan terendah pada kelompok usia 15-24 tahun yaitu sebesar $0,2 \%$. Prevalensi stroke berdasarkan berdasarkan jenis kelamin lebih banyak pada laki-laki $(7,1 \%)$ dibandingkan perempuan $(6,8 \%)$. Berdasarkan tempat tinggal, prevalensi stroke di perkotaan lebih tinggi $(8,2 \%)$ dibandingkan dengan daerah pedesaan $(5,7 \%)$. Prevalensi kasus stroke tertinggi terdapat di Sulawesi Utara $(10,8 \%)$ dan terendah di Provinsi Papua (2,3\%). ${ }^{6}$

Di Kota Manado, khususnya di Instalasi Rehabilitasi medik RSUP Prof.
Dr. R. D. Kandou, hemiparesis merupakan penyakit terbanyak tahun 2011 dengan 211 kasus baru dan sebagai urutan kedua terbanyak pada tahun 2013 dengan persentase $27 \%$ dari total kunjungan pasien, dan kembali menjadi penyakit terbanyak pada 2016 dengan 1.890 kasus. ${ }^{6}$

Hemiparesis adalah sindrom klinis yang awal timbulnya mendadak, progesif cepat, berupa defisit neurologis fokal yang berlangsung 24 jam atau lebih atau langsung menimbulkan kematian, dan semata-mata disebabkan oleh gangguan peredaran darah otak non-traumatic. ${ }^{7}$

Disfungsi motorik yang paling umum adalah hemiparesis karena lesi pada sisi otak yang berlawanan. Hemiparesis atau kelemahan pada satu sisi tubuh merupakan gejala lain dari disfungsi motorik. ${ }^{8}$

Hemiparesis merupakan komplikasi yang sering terjadi setelah serangan stroke. Ditemukan $70-80 \%$ pasien yang terkena serangan stroke mengalami hemiparesis. Sekitar $20 \%$ pasien stroke akan mengalami peningkatan fungsi motorik, tetapi pemulihan pasien yang mengalami hemiparesis bervariasi dan lebih dari $50 \%$ mengalami gejala sisa fungsi motorik. ${ }^{9}$

WHO menyatakan rehabilitasi ialah semua tindakan yang bertujuan untuk mengurangi dampak disabilitas/handikap, agar penca (penyandang cacat) dapat berinteraksi dalam masyarakat. Batasan rehabilitasi sebagai suatu program yang didesain untuk memungkinkan seseorang yang mengalami disabilitas, sakit kronik atau dalam tahap konvalesens untuk dapat hidup dan berkarya seoptimal mungkin dengan kapasitas yang dimilikinya. Dengan pelayanan rehabilitasi yang tepat maka $80 \%$ dari mereka yang tetap hidup dapat berjalan tanpa bantuan, $70 \%$ dapat melakukan aktivitas mengurus diri sendiri, dan $30 \%$ dapat kembali bekerja. ${ }^{10}$

Program rehabilitasi adalah bentuk pelayanan kesehatan yang terpadu dengan pendekatan medik, psikososial, educational vocational yang bertujuan mencapai kemampuan fungsional seoptimal mungkin dan mencegah serangan berulang. Pelayanan rehabilitasi medik diberikan 
dengan pendekatan multidisiplin yang melibatkan dokter (ahli saraf, ahli rehabilitasi medik, ahli penyakit dalam) perawat, fisioterapis, terapis okupasi, pekerja sosial medik, psikolog, terapis wicara, ortotis prostetis, dan lain-lain sesuai problem yang ada pada pasien. Pasien dan keluarga pun turut berperan penting dalam pelayanan rehabilitasi. ${ }^{11}$

Manfaat rehabilitasi medik pada pasien stroke bukan untuk mengubah defisit neurologis melainkan menolong pasien untuk mencapai fungsi kemandirian seoptimal mungkin dalam konteks lingkungannya. Jadi, tujuannya adalah lebih kearah meningkatkan kemampuan fungsional daripada memperbaiki defisit neurologis atau mengusahakan agar pasien dapat memanfaatkan kemampuan yang tersisa untuk mengisi kehidupan secara fisik, emosional, dan sosial ekonomi dengan baik. ${ }^{11}$

Dengan melihat hal-hal di atas, maka peneliti tertarik untuk mengangkat permasalahan tersebut untuk dilakukan penelitian tentang gambaran terapi rehabilitasi medik kepada pasien stroke dengan hemiparesis dekstra atau sinistra.

\section{METODE PENELITIAN}

Jenis penelitian ialah retrospektif deskriptif. Sampel penelitian ialah data rekam medik pasien hemiparesis pasca stroke di Instalasi Rehabilitasi Medik RSUP Prof. Dr. R. D. Kandou Manado. Pengambilan sampel menggunakan metode consecutive sampling sehingga memenuhi total jumlah sampel yang dibutuhkan dan sesuai dengan kriteria inklusi.

Penelitian ini dilakukan kepada pasien stroke dengan hemiparesis dekstra atau sinistra yang mendapat penanganan rehabilitasi medik di Instalasi Rehabilitasi Medik RSUP Prof. Dr. R. D. Kandou Manado periode Januari-Maret 2016. Penelitian berlangsung pada bulan Juli 2016. Variabel penelitian ialah pasien pasca stroke yang mengalami hemiparesis dekstra atau sinistra dan mendapat penanganan rehabilitasi medik di periode Januari-Maret 2016 di Instalasi Rehabilitasi
Medik RSUP Prof. Dr. R. D. Kandou Manado.

\section{HASIL PENELITIAN}

Rentang usia pasien stroke dengan hemiparesis terbanyak ialah antara usia 5160 tahun (40\%) (Tabel 1) dengan persentase hemiparesis pada laki-laki $(66,67 \%)$ lebih tinggi dibandingkan perempuan $(33,33 \%)$ (Tabel 2).

Tabel 1. Jumlah, persentase, dan rata-rata usia dari subjek

\begin{tabular}{ccc}
\hline Usia (tahun) & $\mathbf{N}$ & $\mathbf{( \% )}$ \\
\hline $41-50$ & 6 & 20 \\
$51-60$ & 12 & 40 \\
$61-70$ & 6 & 20 \\
$>70$ & 6 & 20 \\
Total & 30 & 100 \\
\hline
\end{tabular}

Tabel 2. Jumlah dan persentase jenis kelamin dari subjek

\begin{tabular}{ccc}
\hline Jenis kelamin & $\mathbf{N}$ & $(\boldsymbol{\%})$ \\
\hline Perempuan & 10 & 33,33 \\
Laki-laki & 20 & 66,67 \\
Total & 30 & 100 \\
\hline
\end{tabular}

Tabel 3. Jumlah pemberian terapi terhadap pasien pasien hemiparesis

\begin{tabular}{lcc}
\hline \multicolumn{1}{c}{ Jenis terapi } & N & $(\boldsymbol{\%})$ \\
\hline Infra red & 206 & 31,402 \\
Latihan fisik klasik & 182 & 27,744 \\
Latihan aktif kreatif & 120 & 18,293 \\
Adaptasi AKS & 88 & 13,415 \\
USD & 16 & 2,449 \\
Latihan pernapasan & 14 & 2,134 \\
Latihan berbahasa & 4 & 0,610 \\
Psikologi & 12 & 1,829 \\
Proper body mechanism & 12 & 1,829 \\
Terapi sosial medik & 2 & 0,305 \\
Total & 656 & 100 \\
\hline
\end{tabular}

Dari Tabel 3 didapatkan bahwa pemberian terapi yang paling sering diberikan kepada pasien stroke dengan hemiparesis ialah infra merah $(31,402 \%)$, disusul latihan fisik klasik (27,744\%), latihan aktif kreatif $(18,293 \%)$, adaptasi AKS (13,415\%), terapi USD (2,449\%), latihan pernapasan $(2,134 \%)$, latihan berbahasa $(0,610 \%)$, psikologi $(1,829 \%)$, 
proper body mechanism (1,829\%), dan terapi sosial medik $(0,305 \%)$.

\section{BAHASAN}

Upaya dibidang kesehatan pada dasarnya meliputi atas upaya peningkatan (promotif), pencegahan (preventif), penyembuhan (kuratif) dan pemulihan (rehabilitatif). Upaya peningkatan, pencegahan, dan penyembuhan telah mencapai kemajuan dan bahkan telah mencapai hasil-hasil yang sangat menggembirakan, sedangkan upaya pemulihan atau rehabilitatif masih perlu dikembangkan. ${ }^{11}$

Menurut WHO, rehabilitasi ialah semua tindakan yang ditujukan untuk mengurangi dampak disabilitas/handikap, agar memungkinkan penyandang cacat berintegrasi dengan masyarakat, yaitu rehabilitasi medik, rehabilitasi sosial, dan rehabilitasi kekaryaan (vocational rehabilitation. ${ }^{11}$

Meskipun fokus kita selanjutnya terutama pada rehabilitasi medik, namun jangan lupa, bahwa dalam praktik rehabilitasi medik selalu berkaitan dengan rehabilitasi lainnya, dan kegagalan sering terjadi oleh karena memandang rehabilitasi dari satu sisi saja, tidak secara keseluruhan.

Pada penelitian ini, jumlah subjek penelitian laki-laki lebih banyak dibandingkan perempuan. Pemberian terapi yang paling sering diberikan kepada pasien stroke dengan hemiparesis pada periode Januari-Maret 2016 di Instalasi Rehabilitasi Medik RSUP Prof. Dr. R. D. Kandou Manado ialah fisioterapi dengan pemberian infra merah (infra red), disusul latihan fisik klasik, latihan aktif kreatif, adaptasi AKS, terapi USD, latihan pernapasan, latihan berbahasa, psikologi, proper body mechanism, dan terapi sosial medik.

Terapi dengan infra merah lebih banyak diberikan kepada pasien hemiparesis karena terapi ini dapat meningkatkan proses metabolisme dengan adanya kenaikan suhu. Proses metabolisme menjadi lebih baik karena terjadi vasodilatasi pembuluh darah, sehingga sirkulasi darah meningkat. Jadi, pemberian nutrisi dan oksigen kepada jaringan akan ditingkatkan, dan antibodi di dalam jaringan tersebut akan meningkat. Dengan demikian pemeliharaan jaringan menjadi lebih baik, dan juga memengaruhi jaringan otot karena kenaikan suhu selain membantu terjadinya relaksasi juga akan meningkatkan kemampuan otot untuk berkontraksi. Terapi ini dapat mengurangi nyeri, relaksasi spasme otot superfisial, dan meningkatkan aliran darah di area pemberian terapi. ${ }^{12}$

Rehabilitasi medik pasca stroke merupakan suatu upaya terpadu yang melibatkan berbagai disiplin ilmu kedokteran dan merupakan kumpulan program yang meliputi pelatihan, penggunaan modalitas, alat-alat, dan juga obat-obatan. Makin dini rehabilitasi medik dimulai, maka dampaknya akan semakin baik. $^{12}$

Penelitian ini memiliki kelemahan dan keterbatasan seperti kurangnya sampel yang diteliti akibat sedikitnya pasien yang mendapatkan penanganan rehabilitasi medik pada periode Januari-Maret 2016. Peneliti juga hanya meneliti gambaran pemberian terapi tanpa mempertimbangkan efektivitas dari pemberian suatu jenis terapi tertentu.

\section{SIMPULAN}

Dari hasil penelitian dapat disimpulkan bahwa terapi yang paling sering diberikan kepada pasien stroke dengan hemiparesis pada periode Januari-Maret 2016 di Instalasi Rehabilitasi Medik RSUP Prof. Dr. R. D. Kandou Manado ialah fisioterapi dengan pemberian infra merah (infra red), diikuti latihan fisik klasik, latihan aktif kreatif, adaptasi AKS, terapi USD, latihan pernapasan, latihan berbahasa, psikologi, proper body mechanism, dan terapi sosial medik.

\section{SARAN}

Disarankan untuk meningkatkan upaya menurunkan angka stroke dengan hemiparesis melalui penyuluhan kesehatan mengenai pola hidup sehat serta upaya pencegahan dari berbagai macam penyakit. 


\section{DAFTAR PUSTAKA}

1. Wirawan RP. Rehabilitasi Stroke pada Pelayanan Kesehatan Primer. Maj. Kedokt Indon. 2009;59(2):61-73.

2. Elfrida E, Pardede S. Asuhan Keperawatan stroke dengan aplikasi NANDA NIC NOC. [cited 2016 Jun 29]. Available from: http://documents.tips/ documents/ askep-stroke-nondoc.html.

3. De Freitas GR, Bezerra DC, Maulaz AB, Bogousslavsky J. Stroke: background, epidemiology, etiology and avoiding recurrence. In: Barnes M, Dobkin B, Bogousslavsky J, editors. Recovery after Stroke. Cambridge: Cambridge University Press, 2005; p. 1-46.

4. Karema W. Diagnosis dan klasifikasi stroke. In: Siwi R, Supit W, editors. Stroke Up Date. Manado: PERDOSSI Manado, 2002; p. 11.

5. Brandstatater ME. Stroke rehabilitation (3rd ed). Delisa JA, Gans BN, editors. Philadelphia: Lippincott Raven, 2005; p. 1655-76.

6. Arisoy YM. Gambaran NIHSS RSUP Prof. Dr. R. D. Kandou Manado periode Juli 2014 - Juni 2015. eCliniC. 2016;4(1).

7. Mansjoer A. Kapita Selekta Kedokteran Jilid
2 (3rd ed). Jakarta: Media Aesculapius FKUI, 2001.

8. Smeltzer \& Bare. Buku Ajar Keperawatan Medical Bedah Brunner \& Suddart Vol 1 (8th ed). Kuncara Monica Ester, alih bahasa. Jakarta: EGC, 2005.

9. Rydwik E, Eliasson S, Akner G. The effect of exercise of the affected foot in stroke patients--a randomized controlled pilot trial. Clin Rehabil. 2006;20(8):64555.

10. Karema W. Diagnosis dan Klasisfikasi Stroke. Simposium stroke up date 2001. Manado: Bagian/SMF Saraf FK Unsrat/RSUP Manado, 2001.

11. Mohammad F. Pengaruh latihan motor imagery terhadap kekuatan otot ekstremitas pada pasien stroke dengan hemiparesis di Rumah Sakit Umum Daerah Kota Bekasi [Tesis]. Depok: Universitas Indonesia; 2011.

12. Nastiti I. Penatalaksanaan fisioterapi pada kasus post stroke hemiparese dextra di RST. Dr. Soedjono Magelang [Naskah publikasi]. Surakarta: Fakultas Ilmu Kesehatan Universitas Muhammadiyah; 2015. 